\title{
Effect of Base Isolation in Multistoried RC Regular and Irregular Building by Using Response Spectrum Analysis
}

\author{
S. Gyawali ${ }^{*}$, D. Thapa ${ }^{2}$, T. R. Bhattarai ${ }^{3}$ \\ ${ }^{1}$ MS Student, Infrastructure Engineering and Management Program, Department of Civil and Geomatics Engineering, Pashchimanchal Campus, \\ Institute of Engineering, Tribhuvan University, Nepal \\ ${ }^{2}$ Head of Department, Department of Civil and Geomatics Engineering, Pashchimanchal Campus, Institute of Engineering, Tribhuvan University, Nepal \\ ${ }^{3}$ SDE, Bheri Babai Diversion Multipurpose Project, Nepal
}

DOI: $\underline{10.36348 / \text { sjce.2020.v04i05.004 }}$ | Received: 18.07 .2020 | Accepted: 28.07 .2020 | Published: 30.07 .2020

*Corresponding author: Santosh Gyawali

\section{Abstract}

As we know that large population in the world are living in regions of seismic hazards, at risk from earthquakes of varying severity and frequency of occurrence. The significant loss of life and damage of property occurs every year due to earthquake. Here the one of the best solution to mitigate the effect of earthquake on building is base isolation technique. The main mechanism of seismic isolation is to decouple the structure from base by providing seismic isolators. The Lead Rubber Bearing (LRB) is mounted beneath the superstructure in base isolation system. The significant of base isolation device is to minimize the horizontal acceleration transmitted to the superstructure. It is very promising technology to protect different structures from seismic excitation. In this research, GF+4 storied regular, plan irregular (re-entrant corners) and vertical irregular (vertical geometric irregularity) building models were considered for both fixed base and base isolation in SAP. Response spectrum method analysis under IS1893:2002 was conducted in analysis software for the result of seismic performance parameters. The output results of seismic parameters were interpreted and compared. The SAP analysis results were compared and validated by ETABS software. Lead rubber bearings were designed as UBC 97 and used for base isolation. The research concluded that, Plan and vertical irregular LRB building found more seismically performed than regular LRB building however vertical irregular LRB building showed better performance as comparison to plan irregular LRB building.

Keywords: Base isolation, Lead rubber bearing, Response spectrum analysis.

Copyright @ 2020: This is an open-access article distributed under the terms of the Creative Commons Attribution license which permits unrestricted use, distribution, and reproduction in any medium for non-commercial use (NonCommercial, or CC-BY-NC) provided the original author and source are credited.

\section{INTRODUCTION}

Base isolation is a widely adopted technique all over the world for the prevention of buildings and other civil engineering structures from the damaging effect of earthquake ground shaking. Base isolation system decouple the building from the horizontal ground motion induced by earthquake, and offer a very stiff vertical components to the base level of the superstructure in connection to substructure (foundation). It shifts the fundamental natural period, dissipates the energy in damping, and reduces the lateral forces that distributed along the height of the building. Back to hundred years ago \& even to ancient times, base isolation techniques were adopted in traditional ways. Filling the stone ballast of different sizes in layers having large size stone layer below the small sizes layers in thickness varying from $15 \mathrm{~cm}-$ $30 \mathrm{~cm}$, sand filling in foundation and sides of the walls and using pieces of wood(timbers) underneath the load bearing walls are the applied techniques in earthquakeresistant construction regarding on base isolation mechanisms. In traditional buildings, the rolling of the buildings is achieved by providing foundations of the buildings in the form of timber layers. Each timber layers rolling each other and dissipating the excess energy induced by the earthquake. These all traditional design practices is now becoming old for the earthquake resistance. Now base isolation techniques are gaining much more importance for the preservation of museums, data storage, irreplaceable \& valuable buildings, hospitals \& residential building as well. Therefore, base isolation is one of the most widely implemented \& accepted seismic protection systems in earthquake prone areas recently either developed to reduce the earthquake forces acting on the structures or absorbs a part of the seismic energy. 
The concept of base isolation system had been suggested in last few decades and the available technologies and the knowledge of base isolation system are getting mature and well established. Seismic isolation systems are more effective when applied to high stiffness, low-rise buildings, owing to their abilities to alter the characteristic of the building from rigid to flexible. An increasing number of structures to be isolated reflects the fact that base isolation system is gradually becoming accepted as a proven technology in earthquake hazard mitigation.

\section{Statement of the problem}

In traditional period, it was compulsory that the earthquake design of the structure should have regular configuration. But now a day's different irregular configuration of the building structure are designed and constructed rapidly due to commercial purpose or for the aesthetic purpose. From the past earthquake it was observed that, during the earthquake most of the buildings were collapsed due to their irregular configuration in plan and elevation. It has been found that regular shaped buildings perform better during earthquake. This research probably help to focus on base isolation and use of its technique in irregular configuration building for the better seismic performance comparison to regular configuration building. So that any type of building configuration can be constructed over isolation system to mitigate earthquake effect.

\section{Objectives of the study}

The main objective of this research is to compare the effectiveness of seismic behavior of base isolation in regular and irregular multistoried RC frame building by using response spectrum analysis. Specifically, the study intends to achieve the following sub-objectives.

1. To design the lead rubber bearings using UBC 97 code.

2. To identify the modal time period and modal mass participation factor.

3. To identify the base shear, story displacement and story drift.

\section{Limitations of the study}

The main limitation of this study was that, it was totally based on software analysis of building models and there was no any specific geotechnical considerations.

Specifically the limitations of this study are subdivided as follows:

- The material properties and section properties were considered.

- $\quad$ Fixed support and Link support were assigned in SAP 2000v14 for fixed base and base isolated building respectively. An isolated footing was considered as foundation of buildings.
- Only re-entrant corner was considered for plan irregular building and vertical geometric irregularity was considered for vertical irregular building in this study.

- Seismic loads were considered in the horizontal direction only ( $\mathrm{X}$ and $\mathrm{Y}$ ) however seismic loads in vertical direction $(\mathrm{Z})$ were assumed to be insignificant.

\section{METHODOLOGY}

The research is based on analysis of six building models in which two models were geometric regular, another two models were plan irregular and remaining two models were vertical irregular buildings. Regular, plan irregular (re-entrant corners) and vertical irregular (vertical geometric irregularity) buildings were considered for both isolated and non-isolated buildings. Lead rubber bearings were designed for different locations (corner, center and side face column) by considering the maximum gravity load coming on column at the base and were used for further analysis. IS 1893(part 1): 2002 code was applied for response spectrum analysis and UBC 97 code was considered for design of LRB.

The building models considered for research are as follows.

Model 1A: regular RC building with fixed base

Model 1B: regular RC building with LRB

Model 2A: plan irregular RC building with fixed base

Model 2B: plan irregular RC building with LRB

Model 3A: vertical irregular RC building with fixed base

Model 3B: vertical irregular RC building with LRB

\section{Assumptions Building Details}

Some common assumptions were considered for modeling and analysis of buildings. A GF+ story residential building located in seismic zone $\mathrm{V}$ was considered for response spectrum analysis. The plan of the residential building was $28 \mathrm{~m} * 24 \mathrm{~m}$. The total height of the structure was $14 \mathrm{~m}$. The floor height of the building was $3 \mathrm{~m}$. The height of plinth level to foundation was $2 \mathrm{~m}$. The grade of concrete was M25 for beam, column and slab. The grade of steel was Fe415. The thickness of slab, external wall and internal wall were $125 \mathrm{~mm}, 230 \mathrm{~mm}$ and $115 \mathrm{~mm}$ respectively. The cross section of column and beam for regular building were $(500 \mathrm{~mm} * 500 \mathrm{~mm})$ and $(300 \mathrm{~mm} * 400 \mathrm{~mm})$ respectively. Similarly the cross section of column and beam for plan irregular building were $(475 \mathrm{~mm} * 475 \mathrm{~mm})$ and $(300 \mathrm{~mm} * 400 \mathrm{~mm})$ respectively. Again the cross section of column and beam for vertical irregular building were $(550 \mathrm{~mm} * 550 \mathrm{~mm})$ and $(325 \mathrm{~mm} * 425 \mathrm{~mm})$ respectively. These section properties were passed design by SAP analysis. Live 
load on floor was considered as $3 \mathrm{KN} / \mathrm{m}^{2}$. Live load on roof was considered as $1.5 \mathrm{KN} / \mathrm{m}^{2}$. The dead load, floor finish and partition load were considered as $3 \mathrm{KN} / \mathrm{m}^{2}$, $1 \mathrm{KN} / \mathrm{m}^{2}$ and $1 \mathrm{KN} / \mathrm{m}^{2}$ respectively. The response reduction factor was taken as 5 (for special moment resisting frame) and importance factor as 1 (for residential building). The damping ratio was taken as
$5 \%$ (for rigid structure). The zone factor 0.36 was taken for the seismic zone v as per IS 1893: 2002. Density of concrete was considered as $25 \mathrm{KN} / \mathrm{m}^{3}$ and density of masonry wall was considered as $20 \mathrm{KN} / \mathrm{m}^{3}$. The medium soil was assumed for the response spectrum analysis method. Fig-1 represents the geometric plan and elevation of different building models.

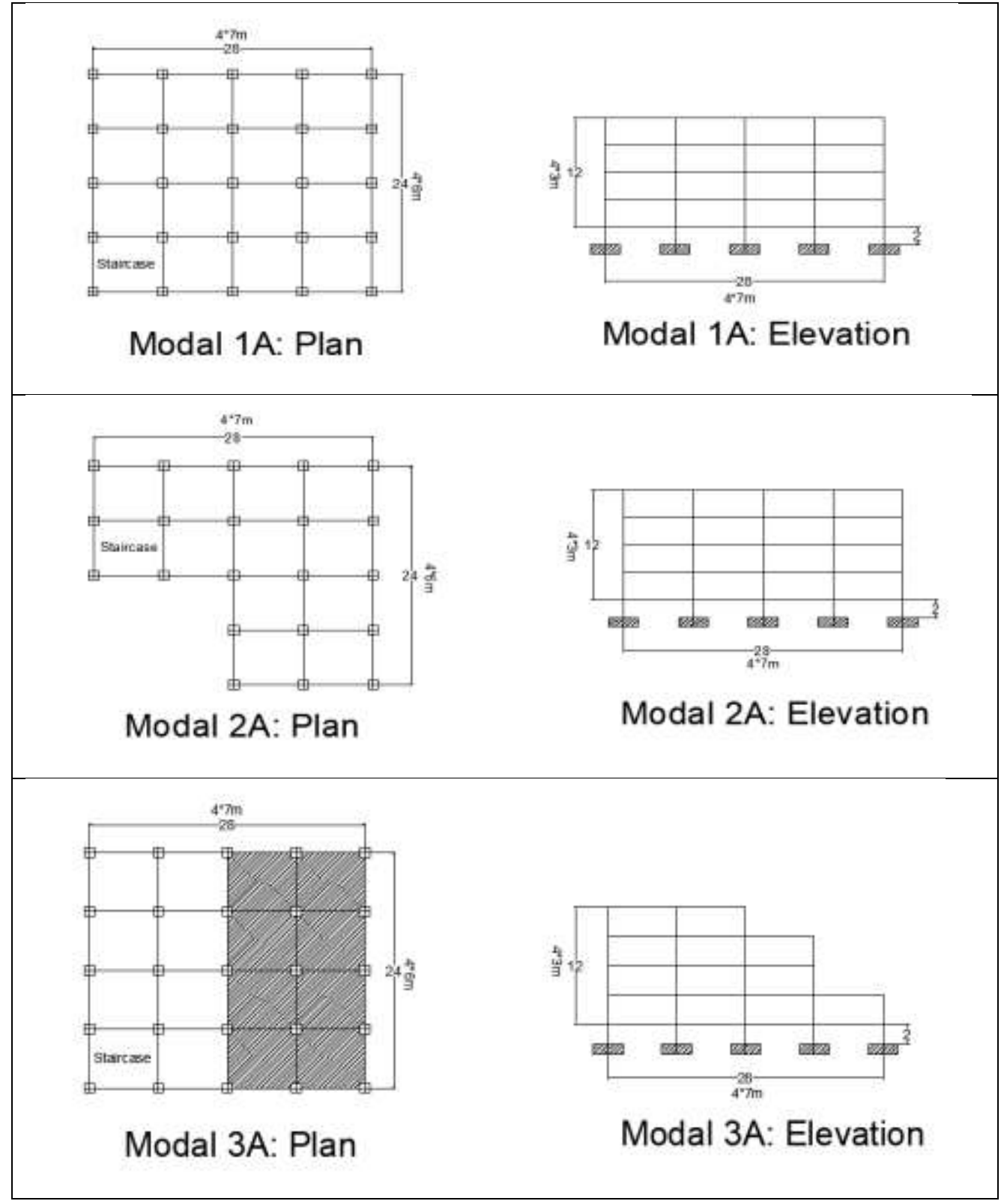

Fig-1: Plan and elevation of different building models

\section{Methodology Steps}

The process of this research belongs to Response Spectrum Analysis Method. Response spectrum method was implemented by using IS 1893:2002 (part 1). Multiple mode of vibrations were used in the frequency domain in this method. The response of the structure is defined as a combination of various special modes. The computer program helped to determine the special mode of structure. All responses were recorded from the design response spectrum for each mode. Design response spectrum is based on modal mass and the modal frequency. After that spectral displacement, maximum displacement, acceleration and base shear were found. LRB isolators were designed as base isolation by using UBC 97 code. These were designed for all models by considering the maximum axial load coming on the column at the base. The building analysis results (seismic parameters) were found by using SAP 2000. Mainly the codes that used 
for the study regarding on response spectrum analysis and base isolation system are as follows:

- IS 1893:2002 (part 1)

- UBC-1997

The steps of research methodology is summarized below:

- $\quad$ SAP 2000v14 was used for model analysis in this research.

- The linear dynamic analysis-response spectrum analysis were done.

- At first, fixed base buildings were modelled and then material and section properties were assigned. Similarly, loads were assigned with reference to IS 875 (part-1, 2).

- Run the fixed base building models for both linear static and response spectrum method and found the standard scale factor for response spectrum analysis.

- The function defined was IS 1893:2000 in Response spectrum analysis in SAP.

- Model analysis of fixed base buildings were done in response spectrum analysis using scale factor obtained and found analysis output results.

- The design of lead rubber bearings were prepared for different buildings for different locations by applying maximum axial load obtained from fixed base model analysis and elastomeric material properties were considered from UBC-97 code.

- Rubber isolators were used as link properties for LRB isolator and assigned all designed values in link properties in SAP.

- Assigned LRB isolators defined, in base support for the base isolated models.

- After assigned respective LRB isolators, run analysis were done for LRB building models.

- Finally base isolated buildings were analyzed by response spectrum method and obtained analysis output results.

- $\quad$ The results obtained from fixed base and LRB buildings were interpreted in tabulated form, compared in graphical form and finally discussed with seismic parameters.

- The conclusion of research was prepared from result and discussions.

- The obtained SAP analysis results were compared and validated by ETABS software.

\section{COMPARISONS OF RESULTS}

Base shear was reduced in LRB buildings with comparison to fixed base buildings. The base shear of $1 \mathrm{~B}$ is reduced $49.914 \%$ in $\mathrm{X}$-direction and $51.363 \%$ in Y-direction with respect to $1 \mathrm{~A}$. Similarly the base shear of $2 \mathrm{~B}$ is reduced $49.321 \%$ in $\mathrm{X}$-direction and $49.954 \%$ in $\mathrm{Y}$-direction with respect to $2 \mathrm{~A}$. Again the base shear of 3B reduced $46.163 \%$ in $X$-direction and $50.131 \%$ in Y-direction with respect to $3 \mathrm{~A}$. Approximately similar results were found on previous research [1]. It showed reduction of base shear from $55 \%$ to $80 \%$ in HDRB building for nonlinear time history analysis.

The top story displacement in 1A was 32.177 $\mathrm{mm}$ and $1 \mathrm{~B}$ was $62.422 \mathrm{~mm}$ in X-direction. The percentage increase was $93.996 \%$ with respect to $1 \mathrm{~A}$. Similarly in 2A it was $30.054 \mathrm{~mm}$ and in $2 \mathrm{~B}$ it was $56.748 \mathrm{~mm}$ in $\mathrm{X}$-direction. The percentage increase was $88.82 \%$ with respect to $2 \mathrm{~A}$. Again in $3 \mathrm{~A}$ it was 28.956 $\mathrm{mm}$ and in $3 \mathrm{~B}$ it was $52.687 \mathrm{~mm}$ in X-direction. The percentage increase was $81.955 \%$ with respect to $3 \mathrm{~A}$. Here the top story displacement in $1 \mathrm{~A}$ was $29.983 \mathrm{~mm}$ and 1B was $59.198 \mathrm{~mm}$ in Y-direction. The percentage increase was $97.439 \%$ with respect to $1 \mathrm{~A}$. Similarly in $2 \mathrm{~A}$ it was $32.224 \mathrm{~mm}$ and in $2 \mathrm{~B}$ it was $61.155 \mathrm{~mm}$ in Y-direction. The percentage increase was $89.781 \%$ with respect to 2A. Again in 3A it was $36.818 \mathrm{~mm}$ and in 3B it was $73.148 \mathrm{~mm}$ in $\mathrm{Y}$-direction. The percentage increase was $98.675 \%$ with respect to $3 \mathrm{~A}$. Khare [2], gave support to these obtained story displacement results. It showed that, LRB buildings had higher values of story displacement than fixed base buildings however very low variations in maximum story displacement were found in base isolated buildings for response spectrum analysis using LRB.

The top story drift in $1 \mathrm{~A}$ was $3.156 \mathrm{~mm}$ and $1 \mathrm{~B}$ was $1.253 \mathrm{~mm}$ in $\mathrm{X}$-direction. The percentage decreased in $1 \mathrm{~B}$ was $60.298 \%$ with respect to $1 \mathrm{~A}$. Similarly in 2A it was $2.916 \mathrm{~mm}$ and in 2B it was 1.109 $\mathrm{mm}$. The percentage decreased in $2 \mathrm{~B}$ was $62.003 \%$ with respect to $2 \mathrm{~A}$. Again in $3 \mathrm{~A}$ it was $4.377 \mathrm{~mm}$ and in $3 \mathrm{~B}$ it was $1.744 \mathrm{~mm}$. The percentage decreased in $3 \mathrm{~B}$ was $60.155 \%$ with respect to $3 \mathrm{~A}$. The top story drift in $1 \mathrm{~A}$ was $2.837 \mathrm{~mm}$ and $1 \mathrm{~B}$ was $1.088 \mathrm{~mm}$ in $\mathrm{Y}$-direction. The percentage decreased in $1 \mathrm{~B}$ was $61.685 \%$ with respect to $1 \mathrm{~A}$. Similarly in $2 \mathrm{~A}$ it was $3.019 \mathrm{~mm}$ and in $2 \mathrm{~B}$ it was $1.170 \mathrm{~mm}$. The percentage decreased in $2 \mathrm{~B}$ was $61.245 \%$ with respect to $2 \mathrm{~A}$. Again in $3 \mathrm{~A}$ it was $4.709 \mathrm{~mm}$ and in $3 \mathrm{~B}$ it was $1.797 \mathrm{~mm}$. The percentage decreased in 3B was $61.839 \%$ with respect to $3 \mathrm{~A}$. Similar pattern of story drift were found on [2], which support these obtained story drift results. Story drifts were reduced by using LRB buildings for response spectrum analysis. It found nearly $60 \%$ reduction of top story drift. Again [1], also showed that reduction rate of story drift for HDRB buildings were up to $60 \%-76 \%$ however nonlinear time history analysis were conducted.

The first three fundamental mode periods found for $1 \mathrm{~A}$ were $0.905 \mathrm{sec}, 0.867 \mathrm{sec}$ and $0.803 \mathrm{sec}$, whereas 1B were $2.072 \mathrm{sec}, 2.039 \mathrm{sec}$ and $1.937 \mathrm{sec}$ respectively. Similarly it found for $2 \mathrm{~A}$ were $0.882 \mathrm{sec}$, $0.851 \mathrm{sec}$ and $0.786 \mathrm{sec}$, whereas in $2 \mathrm{~B}$ it were 1.996 $\mathrm{sec}, 1.971 \mathrm{sec}$ and $1.818 \mathrm{sec}$ respectively. Again it found for $3 \mathrm{~A}$ were $0.806 \mathrm{sec}, 0.787 \mathrm{sec}$ and $0.599 \mathrm{sec}$, whereas in $3 \mathrm{~B}$ it were $1.967 \mathrm{sec}, 1.825 \mathrm{sec}$ and 1.476 sec respectively. The percentage increase in time period 
for first three active mode in 1B were $129.087 \%$, $135.111 \%$ and $141.117 \%$ with respect to $1 \mathrm{~A}$. Similarly it found in 2B were $126.314 \%, 131.566 \%$ and $131.375 \%$ with respect to $2 \mathrm{~A}$. Again it found in 3B were $143.94 \%, 131.723 \%$ and $146.386 \%$ with respect to 3A. Khare [2], gave support to these modal period results. It found natural time period for different modes increased in LRB buildings compared to fixed base buildings for response spectrum analysis.

The modal mass participation factor of different mode in all buildings for $\mathrm{X}, \mathrm{Y}$ and $\mathrm{Z}$ direction were found. The combined modal mass participation should be more or equal to $90 \%(0.9)$ of the actual mass in each orthogonal response direction. The first two modes should be translation and torsion should only come third mode or later. These were valid in all building models. In $1 \mathrm{~A} 84.722 \%$ of mass was participated in translation $\mathrm{X}$-direction in $1^{\text {st }}$ mode, $84.329 \%$ of mass was participated in translation Ydirection in $2^{\text {nd }}$ mode and $34.804 \%$ of mass was participated in torsion Z-direction in $3^{\text {rd }}$ mode, whereas in 1B $95.473 \%$ of mass was participated in translation $\mathrm{X}$-direction in $1^{\text {st }}$ mode, $93.483 \%$ of mass was participated in translation Y-direction in $2^{\text {nd }}$ mode and $54.806 \%$ of mass was participated in torsion Z-direction in $3^{\text {rd }}$ mode. Similarly in $2 \mathrm{~A} 84.767 \%$ of mass was participated in translation $\mathrm{X}$-direction in $1^{\text {st }}$ mode, $79.111 \%$ of mass was participated in translation $\mathrm{Y}$ direction in $2^{\text {nd }}$ mode and $34.966 \%$ of mass was participated in torsion Z-direction in $3^{\text {rd }}$ mode, whereas in model 2B $98.669 \%$ of mass was participated in translation $\mathrm{X}$-direction in $1^{\text {st }}$ mode, $94.609 \%$ of mass was participated in translation Y-direction in $2^{\text {nd }}$ mode and $33.398 \%$ of mass was participated in torsion Zdirection in $3^{\text {rd }}$ mode. Again in $3 \mathrm{~A} 55.624 \%$ of mass was participated in translation $\mathrm{Y}$-direction in $1^{\text {st }}$ mode, $72.69 \%$ of mass was participated in translation $\mathrm{X}$ direction in $2^{\text {nd }}$ mode and $43.578 \%$ of mass was participated in torsion Z-direction in $3^{\text {rd }}$ mode, whereas in model 3B $70.991 \%$ of mass was participated in translation $\mathrm{Y}$-direction in $1^{\text {st }}$ mode, $97.788 \%$ of mass was participated in translation X-direction in $2^{\text {nd }}$ mode and $64.455 \%$ of mass was participated in torsion $\mathrm{Z}$ direction in $3^{\text {rd }}$ mode.

\section{RESULTS AND DISCUSSIONS}

If the building has higher value of base shear, it indicates that the building is stiff under earthquake ground motions and similarly the lesser value of base shear indicates that the building is flexible under earthquake ground motion. Modal displacements were increased in every story after providing LRB which is important to make a structure flexible during earthquake. Story drift were reduced in higher stories which makes structure safe against earthquake. Natural time period value depends on the building flexibility and mass, more the flexibility the longer is the Time period and more the mass the longer is the Time period. Modal mass participating ratio is a measure of energy contained with each resonant mode since it represents the amount of system mass participating in a particular mode.

Here the percentage reduction of base shear was found maximum on $1 \mathrm{~B}$ and minimum on $3 \mathrm{~B}$ as compared to $2 \mathrm{~B}$. $2 \mathrm{~B}$ model gave better performance than $3 \mathrm{~B}$ model regarding on base shear. The percentage increase of top story displacement in X-direction found maximum on $1 \mathrm{~B}$ and minimum on $3 \mathrm{~B}$ as compared to $2 \mathrm{~B}$ however the percentage increase in $\mathrm{Y}$-direction found maximum on $3 \mathrm{~B}$ and minimum on $2 \mathrm{~B}$ as compared to $1 \mathrm{~B}$. By observing story displacements $3 \mathrm{~B}$ found better than $1 \mathrm{~B}$ and $2 \mathrm{~B}$. The percentage reduction of top story drift in $\mathrm{X}$ direction found maximum on $2 \mathrm{~B}$ and minimum on $3 \mathrm{~B}$ as compared to $1 \mathrm{~B}$ however percentage reduction of top story drift in $\mathrm{Y}$ direction found maximum on $3 \mathrm{~B}$ and minimum on $2 \mathrm{~B}$ as compared to $1 \mathrm{~B}$. Similar as story displacement, 3B found better than $1 \mathrm{~B}$ and $2 \mathrm{~B}$ regarding on reduction story drift. The percentage increase of time period on first three active modes were found maximum on $3 \mathrm{~B}$ and minimum on $2 \mathrm{~B}$ as compared to $1 \mathrm{~B}$. $3 \mathrm{~B}$ had higher time period than others. The percentage mass participation factor on translation first two modes were found maximum on $1 \mathrm{~B}$ and $2 \mathrm{~B}$ as compared to $3 \mathrm{~B}$, while the percentage mass participation factor on torsion in third mode was found maximum on $3 \mathrm{~B}$ and minimum on $2 \mathrm{~B}$ as compared to $1 \mathrm{~B}$. Translation wise there found similar patterns in three LRB buildings but in rotational, $3 \mathrm{~B}$ showed better performance than other LRB buildings.

\section{VALIDATION OF THE RESULTS}

Here the research is based on computer based software program SAP 2000v14. The validation of SAP output data were done by comparing the results of another similar software program ETABS v16. SAP and ETABS both are design oriented software program. The ETABS is also known as building design software program. Here SAP data validation were done by comparing the ETABS output data. The compared data were shown in graphical form. 


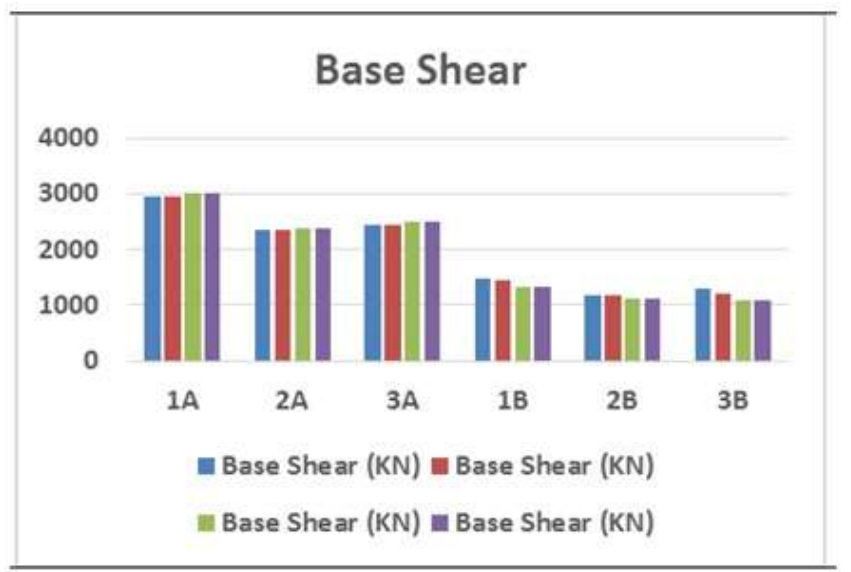

Fig-2: Validation for base shear
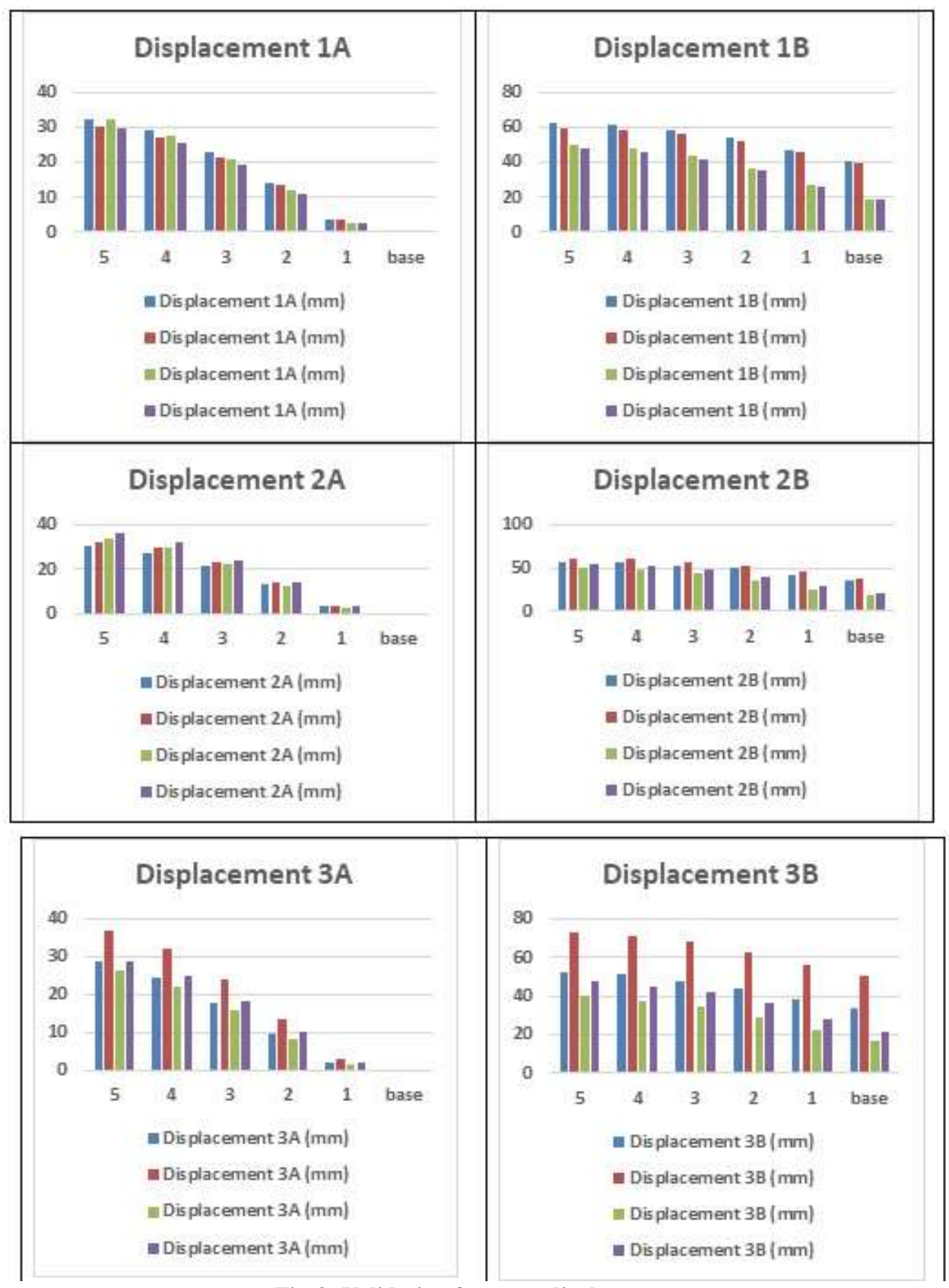

Fig-3: Validation for story displacement 

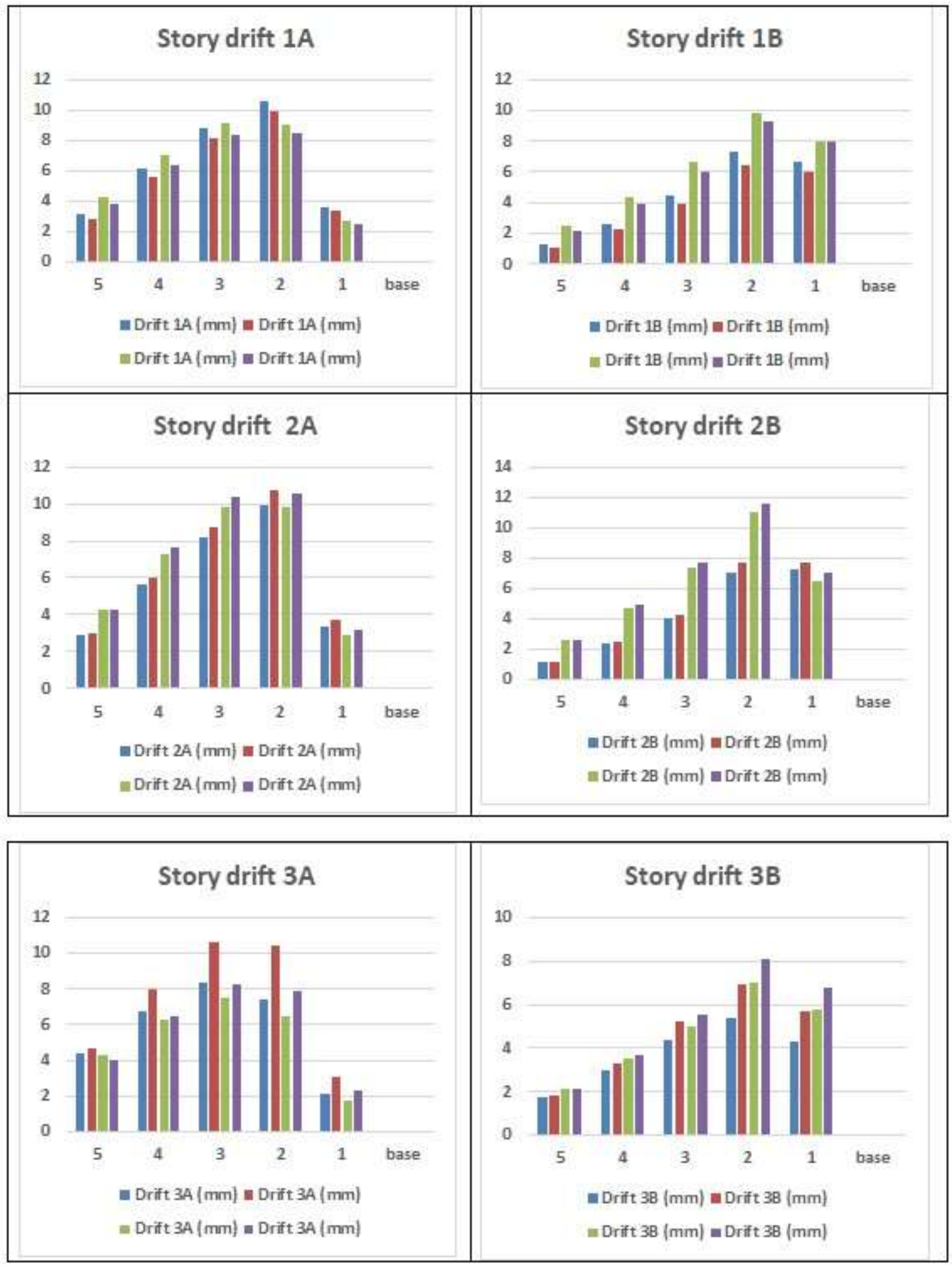

Fig-4: Validation for story drift 


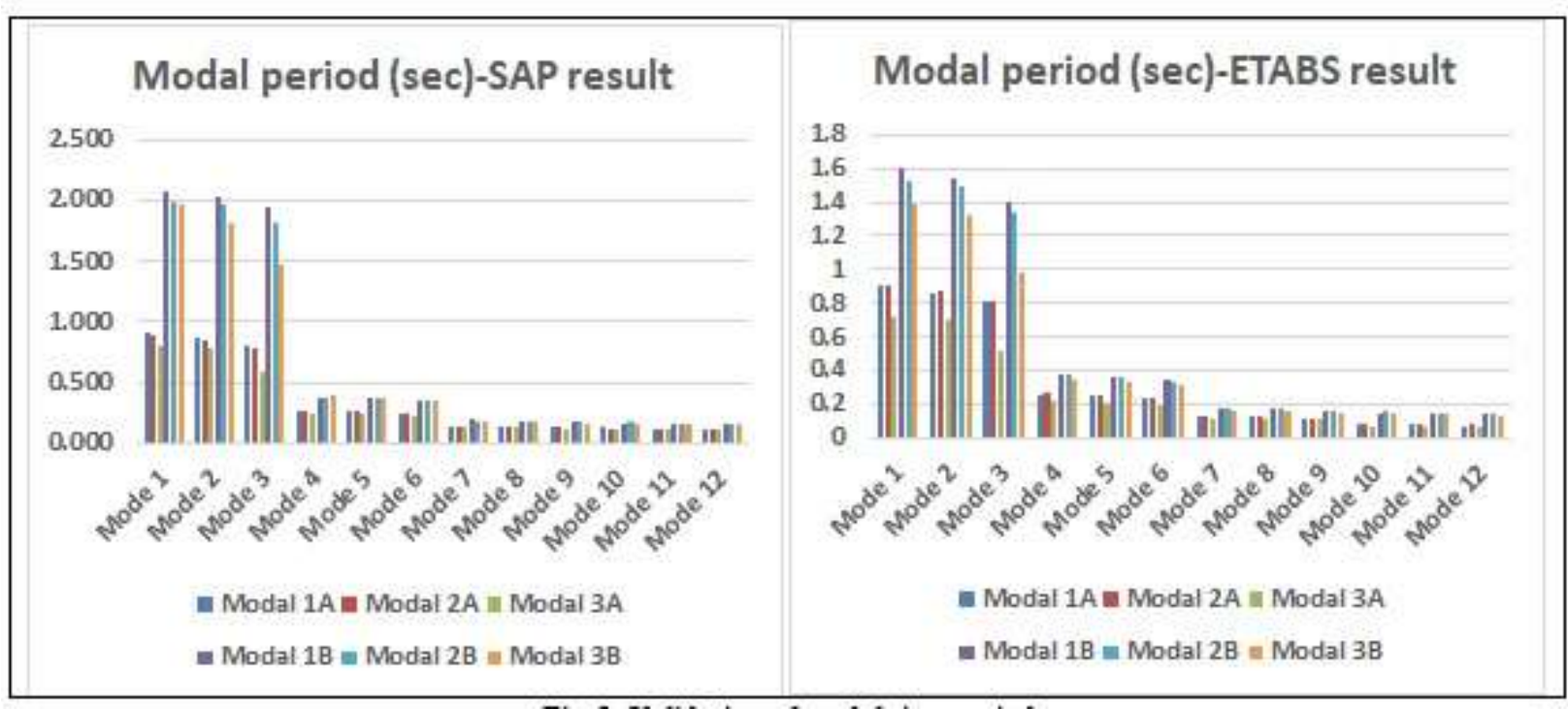

Fig-5: Validation of modal time period

The combined modal mass participation factor for both SAP and ETABS result in respective directions were almost equal to each other.

There were some small variations in SAP and ETABS results, however the graph and percentage ratios were nearly similar. Default different values and functions generated in respective software made the output results variation. Overall the output results of SAP and ETABS were match for each other. The modelling and analysis process was right. That is why these data were feasible and the research process was valid.

\section{CONCLUSION}

The output results of seismic parameters were obtained from analysis software SAP. The results were analyzed, interpreted and compared. SAP analysis results were compared with ETABS software for validation. The findings of research are as follows.

- The base shear value in LRB building has been reduced up to 45 to $50 \%$ as compared to fixed base building.

- Top story displacement of building has been increased up to 81 to $99 \%$ by using LRB.

- Top story drift of building has been decreased up to 60 to $62 \%$ by using LRB.

- The first three mode of fundamental time period of building has been increased up to 126 to $147 \%$ by using LRB.
- In overall, plan and vertical irregular base isolated building showed better seismic performance than regular base isolated building.

- Among plan irregular and vertical irregular base isolated building, vertical irregular base isolated building found better strength and seismic performance.

- Vertical irregular base isolated building also found better torsional safe than other base isolated buildings.

Finally this research concluded that LRB irregular buildings are more effective than LRB regular buildings regarding on seismic performance under response spectrum analysis.

\section{REFERENCES}

1. Majage, S. C., \& Phadatare, P. N. P. (2018). Design of high damping rubber Isolator for RC Multistoried Structures and its Comparative Seismic Analysis. 5(8):553-558.

2. Khare, G. P. (2018). Analysis of the Base Isolated Building (Lead Plug Bearing) in Etabs. International Research Journal of Engineering and Technology. 5(1), 404-410. Retrieved from www.irjet.net. 